\title{
Alijäämien historian lyhyt oppimäärä
}

\section{Matti Ylönen}

Yanis Varoufakis: Maailmantalouden Minotauros. Vastapaino 2014. Suomentanut Hannu Laurila ja työryhmä. Alkuteos The Global Minotaur. America, the True Origins of the Financial Crisis and the Future of the World Economy.

Harva asia määrittää yhtä paljon maailmantalouden pitkän aikavälin kehitystä kuin kaupan ja rahavirtojen tasapainot. Suurvaltojen nousut ja laskut, finanssikriisit ja niitä seuraavat velkakriisit ovat yleensä aina seurausta pitkään jatkuneista epätasapainotiloista.

Kreikkalainen taloustieteilijä Yanis Varoufakis kuvaa Maailmantalouden Minotauroksessa ansiokkaasti näiden epätasapainotilojen poliittista taloustiedettä 1900-luvun alkupuolelta nykypäivään asti. Laajaa kansainvälistä huomiota kerännyt kirja on tervetullut lisä suomalaiseen poliittisen taloustieteen kirjallisuuteen.

Varoufakis lähti kirjoittamaan alun perin kirjaa eurokriisistä. Lopputulos kertoo kuitenkin enemmän Yhdysvaltojen talouspolitiikan suurista trendeistä ja murrosvaiheista. Hyvä niin, sillä Varoufakiksen valitsema näkökulma on tuore ja tarpeellinen.

Kirjan painopiste on erityisesti vuoden 1971 jälkeisessä Yhdysvaltojen talous-, raha- ja ulkopolitiikassa. Tälle järjestelmälle Varoufakis on antanut nimen Minotauros. Sen ymmärtäminen vaatii palaamista yli 25 vuotta aiemmin käytyihin Bretton Woods -neuvotteluihin.

Toisen maailmansodan jälkeen Bretton Woodsin kylässä New Hampshiren osavaltiossa Yhdysvalloissa rakennettu maailmantalouden hallintajärjestelmä rakentui kahden pilarin varaan. Kansainvälisen valuuttajärjestelmän pohjaksi otettiin dollari, jonka arvo oli sidottu Yhdysvaltojen toisen maailmansodan aikana kerryttämiin kultavarantoihin. Muiden valuuttojen arvo sidottiin tämän jälkeen dollariin.

Järjestelmän toisen pilarin muodostivat Bretton Woods -järjestöt Maailmanpankki ja Kansainvälinen valuuttarahasto IMF. Kansainvälisen valuuttarahaston tehtäväksi annettiin avustaa valtioita, joille valuuttakurssin ylläpidosta tuli ongelma. Mukana neuvotteluissa oli myös aikansa merkittävimmän 
taloustieteilijän John Maynard Keynesin ehdotus bancor-reservivaluttaaan perustuvasta järjestelmästä. Siinä valuutat olisi sidottu uuteen bancor-valuuttaan. Valtioita olisi kannustettu pitämään tuonti ja vienti tasapainossa perimällä korkoa mailta vuoden lopun bancor-saldoista.

Keynesiä ajoi huoli siitä, että kaupan epätasapainojen maailmassa pienikin kriisi voisi helposti levitä uudeksi kansainväliseksi talouskatastrofiksi, koska kaupan alijäämät kulkevat usein käsi kädessä budjettialijäämien kanssa. Yhdysvallat halusi kuitenkin dollarin reservivaluutaksi, ja sodan voittajavaltiona se pystyi kävelemään Keynesin ehdotuksen yli.

Yhdysvallat käynnisti maailmantalouden uudelleen etenkin Eurooppaan suunnatun Marshall-avun kautta. Se auttoi rakentamaan maanosan teollisuuden perustan, ja saatuja rahoja kierrätettiin takaisin Yhdysvaltoihin josta ostettiin korkean teknologian tuotteita. Myös Japani nousi samantyyppisellä Yhdysvaltojen tuella. Varoufakis kutsuu tätä aikakautta maailmantalouden Tiekartaksi. Yhdysvalloista tuli uuden maailmanjärjestyksen keskipiste, ja se oli valmis maksamaan asemastaan Saksan ja Japanin tukemisen vaatiman hinnan.

Vuonna 1971 maailmantalouden tuulet kääntyivät. Yhdysvallat ei Vietnamin sodan jälkeen pystynyt enää ylläpitämään dollarin kultakytköstä, ja dollari sai vastedes pärjätä omillaan. Tiekartan romahtaminen ei ollut suunniteltua, mutta Yhdysvallat sopeutui nopeasti tilanteeseen.

Keinoksi valikoitui Varoufakiksen sanastossa "Minotauroksen labyrintti". Yhdysvallat alkoi pyörittää kiihtyvästi kasvavien kauppa- ja rahavirtojen järjestelmää, joka johti Yhdysvaltojen kaksoisalijäämään, kun kauppatase ja julkinen budjettitalous painuivat molemmat yhtä aikaa miinus-merkkisiksi. Aivan kuten Kreikan mytologian Minotauros, myös maailmantalouden Minotauros vaati uhreja syödäkseen. Muut maat päätyivät rahoittamaan Yhdysvaltojen hyvinvointia.

Minotauroksen aiheuttama velkaantuminen ei ollut ongelma Yhdysvalloille niin kauan, kuin kansainväliset sijoittajat olivat valmiit ostamaan Yhdysvaltojen velkakirjoja. Dollari oli edelleen maailmantalouden keskusvaluutta, joten sijoittajien katoa ei tarvinnut pelätä. Valuuttojen loputon virta Yhdysvaltoihin kasvatti myös Wall Streetin finanssikeskusta, etenkin sen jälkeen kun pääomaliikkeiden rajoitukset purettiin 1970-luvun lopulta alkaen. 
Vuosien 2007-2009 finanssiriisin jälkeen koitti epävarmuuden aika. Varoufakis toteaa, että "peto on pitkällään, eikä kukaan enää hoida sen tehtävää Amerikan kaksoisalijäämien tasapainottajana ja maailmantalouden ylijäämien imurina." Yhdysvallat ja etenkin Wall Street imee yhä pääomia muualta maailmasta, mutta Minotauroksen vanha valta ei enää palaa, Varoufakis ennustaa. Seurauksena on aiempaa moninapaisempi maailma.

Kun uutta hegemonia ei ole nousemassa, olisi tarve globaalille yli- ja alijäämien kierrätysmekanismille suurempi kuin koskaan. Tämä edellyttäisi kuitenkin poliittista halua tämän päivän versioon bancorista. Varoufakiksen suurin toivo tällaisen mekanismin synnyttämiseksi on kehittyvissä talouksissa, mutta vain suurin varauksin. Kierrätysmekanismia tarvittaisiin myös Euroopan unionissa. Etelä-Euroopan velkakriisi oli paljossa tulosta yhteisvaluutta-alueen sisäisistä kilpailukykyeroista, kun pohjoisen vahvat valtiot veivät tuotteita velkaantuviin Etelä-Euroopan maihin.

Maailmantalouden Minotauros on poikkeuksellinen kirja suomenkielisessä tietokirjallisuudessa. Maailman suurien mullistusten ja kehityskulkujen kuvaaminen yhden kattokäsitteen kautta tuo mieleen yhdysvaltalaisen populaarin tietokirjallisuuden. Tämäntyyppiset kirjat seisovat tai kaatuvat sen mukana, miten hyvin kattokäsite onnistuu kuvaamaan monisyistä maailmaa. Minotauros-vertaus kantaa riittävän hyvin. Talouskirjaksi Minotauros on myös yhdysvaltalaisten verrokkiensa tavoin helppolukuinen. Tämä on onnistuttu tekemään sisällön nyansseista tinkimättä. Se on saavutus.

Kirja on myös hyvin suomennettu. Tampereen yliopiston kansantaloustieteen professorin Hannu Laurilan johtama työryhmä on tehnyt työtä pieteetillä, ja onnistunut löytämään yhtenäisen äänen.

Ennen kaikkea Minotauros on piristävä tuulahdus usein varsin historiattomaan talouskeskusteluun. Taloudellista kerrontaa rytmitetään maailmanpolitiikan analyysilla. Tässä mielessä Minotauros on poliittista taloustiedettä parhaimmillaan. 